\title{
ECOSYSTEM SERVICES IN ENERGY CROP PRODUCTION - A CONCEPT FOR REGULATORY MEASURES IN SPATIAL PLANNING?
}

\author{
Gerd LuPP, JUliane Albrecht, MARIANnE DARBI, OlaF BASTIAN
}

Leibniz-Institute of Ecological Urban and Regional Development, Weberplatz 1, D-01217 Dresden, Germany, Phone: +49 351-4679-0,e-Mail: g.lupp@ioer.de; j.albrecht@ioer.de, m.darbi@ioer.de,o.bastian@ioer.de

Received: $9^{\text {th }}$ August 2010, Accepted: $9^{\text {th }}$ September 2011

\begin{abstract}
Land management faces huge challenges to fulfill increasing demands for limited natural resources and to safeguard sustainable land use. The CBD stresses the necessity to minimize land use conflicts and to improve the management of landscapes. Therefore favourable strategies and methods have to be developed.

According to European and German energy policies, the proportion of renewable resources for energy is to be increased significantly in the coming years. The extended cultivation of energy crops can lead to conflicts, e.g. severe impacts on various ecosystem services based on groundwater, soils, biodiversity and the overall appearance of the landscape scenery. Energy crops compete in space with food production, and they have various ecological, economic and social effects. There is a need for suitable spatial planning instruments to regulate energy crop cultivation and to reduce the impact on ecosystems and landscapes.

As it includes all levels of sustainability with economic, ecological and social aspects, the concept of Ecosystem Services can be a stimulus and a suitable tool to find appropriate solutions. On the one hand, it will be shown that ecosystem services are suited to assess the consequences of energy crops. On the other hand, it is discussed whether and how regulatory measures and methods in spatial planning consider ecosystem services and if they contribute to govern land use management.
\end{abstract}

Key words: Renewable Energy, Biomass, Maize, Short Rotation Coppices, Biogas, Protected Areas, Moritzburg Small-Hill Landscape, energy crops, nature conservation, regulatory measures, planning instruments

\section{INTRODUCTION}

\section{Policy Goals for Renewable Energy Production and their Effects on Landscape}

The renewable energy roadmap sets out a strategy for a mandatory target of $20 \%$ for renewable energy share of energy consumption in the EU by 2020 (Commission of the European Union 2007). These ambitious goals are set to reduce dependency on imported oil and gas while reducing greenhouse gas emissions significantly (Commission of the European Union 2007). Apart from wind energy, the main contribution to this goal is seen 
in an increased biomass production (Kavalov \& Petkeves 2005). The Committee on Agriculture and Rural Development of the European Parliament considered that the contribution of biomass derived energy to the EU primary energy mix was already $10 \%$ in 2010. Biomass provided for energy production has to double in the coming years to reach the roadmap goals (Commission of the European Union 2007).

On the one hand, the cultivation of energy crops can be - under certain circumstances economically efficient and has positive effects on the environment. Seen as sustainable in the last decade, the bio-energy sector has received a lot of governmental support in many countries and is still expected to take an important role in the future energy supply mix (Bruell 2007). On the other hand, due to the direct and indirect effects, the growth of biomass especially for bio-fuels has also been subject to a wide spread criticism. The national strategy for sustainability in Germany as well as the biomass action plan of the Federal German Government point out that the growing cultivation of renewables increases the competition with space needed for animal food or feed production (BMELV \& BMU 2009). Certain biomass production practices can threat ecosystem services and oppose sustainable development, i.e. it can have severe impacts on waters, soils, biological diversity and landscape qualities (Lee et al. 2008). Guidelines and standards for biomass production are demanded (e.g. Kavalov \& Petkeves 2005) as well as a set of spatial instruments for regulating the impacts on both spatial and site level (SRU 2007).

In the different international, European and national political strategies, the National Strategy on Biological Diversity and the Strategy on Agro-Biodiversity in Germany, provisions are set to foster the development of renewable energies and biomass production, e.g. mission statement "renewables" in the Strategy on Agro-Biodiversity (BMELV 2009). However, energy crops only cover one aspect of this broad strategic orientation. Thus, they are mostly addressed within agricultural development and often not specifically put into the overall landscape context. More generally, according to the Convention on Biological Diversity (CBD) and for achieving a sustainable development, land use conflicts have to be minimized, and guidelines for landscape development have to be optimized. In terms of growing energy crops, the Commission of the European Union worked out a EU biomass action plan and demanded for the preparation of national action plans. The German Biomass Action Plan (BMELV \& BMU 2009) names climate protection and creation of added value in the region as main goals to increase the amount of biomass for energy generation, but also environmental and sustainability aspects like protecting biodiversity, soil fertility, pollution control and water protection have to be considered. The German National Strategy on Biological Diversity demands considering biodiversity issues as well as developing specifications for integrating renewable energy in spatial planning (BMU 2007). In order to implement this into practice, regulatory measures and guidance are needed. The first step towards this can be seen in the German Biomass-ElectricitySustainability Ordinance that demands obligatory certification mechanisms (see below). Therefore it is necessary to set a baseline for Environmental Minimum Requirements (Crossrail 2005, Commission of the European Union 1999). This can be reached by the definition of thresholds and Safe Minimum Standards (Ciriacy-Wantrup 1952) in order to draw a bottom line for the performance of environmental functions (Bastian et al. 2007). Below this line, an ecosystem function is put in to risk. These Safe Minimum Standards can be one approach to utilize the precautionary principle and to apply various sustainability principles into practice (SRU 2002). Main issues are the involvement and participation of stakeholders as well as creating acceptance among the wider public by communication and consultancy (BMELV \& BMU 2009). 


\section{METHODOLOGY}

The aim of the paper is to discuss the impacts of an increased biomass production for energy purposes on ecosystem services. Based on a literature review, the concept of Ecosystem Services has been introduced and tested, whether this is a suitable approach to describe the effects of an increased production of biomass for energy production. Various regulatory measures on European, German and federal levels are being analyzed and evaluated in order to find out in which way they can influence the cultivation of energy crops. In a case study in the Moritzburg Small-Hill Landscape (Saxony, Germany), the onsite regulation and effects of providing maize for a biogas plant in the study area were analyzed, regarding impacts on selected ecosystem services and biodiversity in the study area.

Fig. 1: Map Moritzburg Hilly Area

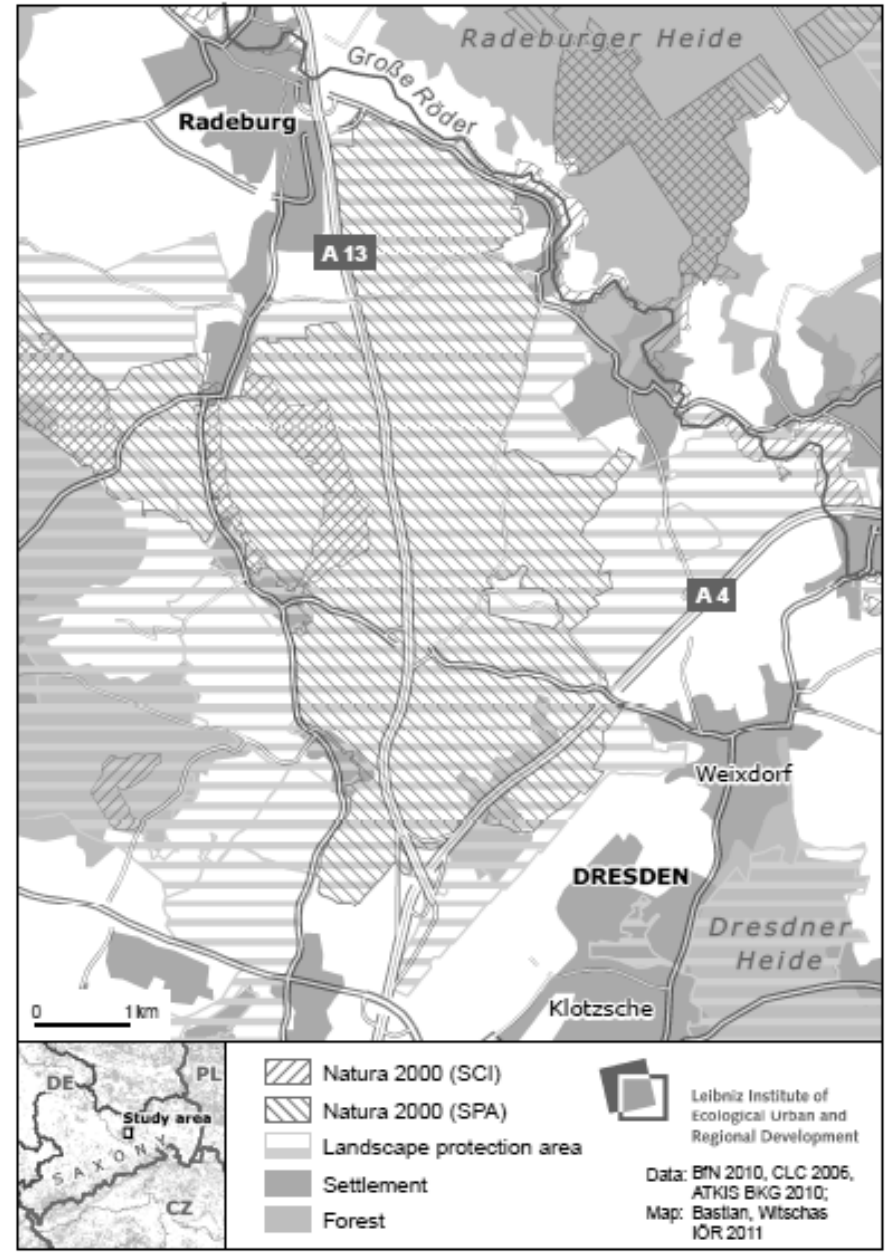




\section{THE CONCEPT OF ECOSYSTEM SERVICES IN THE CONTEXT OF ENERGY CROP PRODUCTION}

Regarding the growing human pressure on the global ecosystem, as expressed in such phenomena as the tremendous loss of Biological diversity or energy and climate problems, it is becoming ever more urgent to control the various and increasing claims upon limited resources, and to ensure sustainable land use. In this regard, the concept of Ecosystem Services is currently largely determining the debate in the area of sustainable land use management.

The basis for the concept of Ecosystem Functions, Goods and Services is a multilayered approach to the interface between environmental and societal claims, with a special consideration of economic aspects (Costanza 1991, Hampicke 1992). However, these are closely connected to ecological and social aspects, resulting in the integration across all three pillars of sustainability.

Ecosystem services describe the benefits people obtain from ecosystems. They are also defined as direct and indirect contributions of ecosystems to human well-being (De Groot et al. 2002). According to the Millennium Ecosystem Assessment (MEA 2005), they include supporting services (e.g. nutrient cycling), provisioning services (e.g. food), regulating services (e.g. climate regulation) and cultural services (e.g. aspects of recreation and tourism). The attractiveness of the concept of Ecosystem Services is based on its integrative, interdisciplinary and transdisciplinary character, as well as its linking of environmental and socio-economic aspects (Müller \& Burkhard 2007). Its great political relevance has been expressed e.g. in the Millennium Ecosystem Assessment (MEA 2005) and in TEEB (2009).

The concept of Ecosystem Services also aims to measure different services of nature, which are often "complimentary" or public goods without any or a very limited market (Hardin 1968). The assessment of services should use the same scales and include all levels of sustainability comprising ecological, economic and social aspects. A common scale is to be achieved including direct and indirect market mechanisms (Costanza et al. 1997). However, still some critics evolve by valuating non-market goods in monetary terms (e.g. Spangenberg 2008).

Both European and member states policies explicitly address a number of goals on different levels related with bio-energy production, e.g. protection of the environment, creating regional added value and employment in rural and peripheral areas. Impacts and effects of these strategies are to be assessed regarding all levels of sustainability.

Including economic, ecological and social aspects, the concept of Ecosystem Services addresses all these levels of sustainability, and it can be used as a stimulus and as a tool to find appropriate solutions to balance the production of renewable energy with other, often complimentary, goods and services provided by multifunctional landscapes. As demonstrated in the following chapter, an increasing cultivation of energy crops can affect various ecosystem functions and services. Core topics are the competition with other goods, e.g. production of food or drinking water, regulating services (e.g. climate protection, water run-off mitigation, water pollution control) and socio-cultural services (scenery and recreation opportunities). A set of applicable methods (e.g. Bastian \& Schreiber 1999) exists to analyze these aspects, especially from an ecological point of view.

\section{Impacts of increased energy crop production on ecosystem services}

Currently, there is an intense dispute on impacts of an increased cultivation of energy crops and resulting impact on ecosystem services. Some of the key arguments are listed in 
Table 1, with a focus on annual energy crops of maize, cereals and perennial short rotation coppices.

\section{Table 1: Impacts of energy crops on ecosystem services}

Based on Bardt et al. 2008, Börjesson 1999a, Börjesson 1999b, Bringezu \& Stegner 2005, Burger 2005, Cherubini \& Strommann 2010, Ericsson et al. 2009, Greiff et al. 2010, Heitmann et al. 2000, Hillier et al. 2009, Kort et al. 1998, Lee et al. 2008, Liesebach \& Mulsow 2003, Londo et al. 2004, Mc Laughlin \& Walsh 1998, NABU 2005, Rode et al. 2010, Rowe et al. 2009, SRU 2007, Windhorst et al. 2004

\begin{tabular}{|c|c|c|c|}
\hline Ecosystem services & Factors & $\begin{array}{l}\text { Impacts of Annual Crops } \\
\text { (Maize, Rape and Corn) }\end{array}$ & $\begin{array}{l}\text { Impact of Short Rotation } \\
\text { Coppices }\end{array}$ \\
\hline \multicolumn{4}{|l|}{ Provisioning services } \\
\hline $\begin{array}{l}\text { Supply of plant } \\
\text { biomass (for food, } \\
\text { fodder and energy) }\end{array}$ & $\begin{array}{l}\text { Land use forms, } \\
\text { crop rotation }\end{array}$ & $\begin{array}{l}\text { Rising prices for products, } \\
\text { buying or renting estates, } \\
\text { shortage of food, poor crop } \\
\text { diversity, monocultures, } \\
\text { sometimes conversion from } \\
\text { grassland to arable fields }\end{array}$ & $\begin{array}{l}\text { Sometimes conversion of } \\
\text { grassland to coppice }\end{array}$ \\
\hline Income & $\begin{array}{l}\text { Income of land } \\
\text { owners and } \\
\text { farmers }\end{array}$ & $\begin{array}{l}\text { Additional income } \\
\text { opportunities for farmers, } \\
\text { however mainly driven by } \\
\text { subsidies and payments for } \\
\text { energy, possibility to decide for } \\
\text { different crops annually } \\
\text { according to market demands }\end{array}$ & $\begin{array}{l}\text { New income opportunities, } \\
\text { however mainly driven by } \\
\text { subsidies and payments for } \\
\text { energy, no choice to change } \\
\text { crops within } 20-30 \text { years } \\
\text { periods, no quick reaction on } \\
\text { new market opportunities } \\
\text { possible }\end{array}$ \\
\hline Water supply & $\begin{array}{l}\text { Water levels, } \\
\text { moisture content in } \\
\text { soils }\end{array}$ & $\begin{array}{l}\text { Amount of ground-water is } \\
\text { reduced due to water demand } \\
\text { of crops, water quality lowered } \\
\text { due to high application of } \\
\text { fertilizers and herbicides }\end{array}$ & $\begin{array}{l}\text { Influence on ground-water due } \\
\text { to water demand, higher } \\
\text { interception of coppice, better } \\
\text { water quality (less fertilizers } \\
\text { and herbicides are needed } \\
\text { compared to annual crops) }\end{array}$ \\
\hline \multicolumn{4}{|l|}{ Regulation services } \\
\hline \multirow[t]{2}{*}{ Carbon sequestration } & $\begin{array}{l}\text { Energy } \\
\text { consumption for } \\
\text { fertilizing, } \\
\text { harvesting and } \\
\text { treatment }\end{array}$ & $\begin{array}{l}\text { Saving fossil fuels, however } \\
\text { relatively large input of (fossil) } \\
\text { energy for cultivation of crops } \\
\text { (fertilizers etc.) }\end{array}$ & $\begin{array}{l}\text { Saving fossil fuels, rather low } \\
\text { (fossil) energy input, if wood is } \\
\text { only chipped, energy input } \\
\text { increases when technically } \\
\text { dried or further processed }\end{array}$ \\
\hline & $\begin{array}{l}\text { Carbon storage, } \\
\text { emission of } \\
\text { greenhouse gases } \\
\text { (GHG) }\end{array}$ & $\begin{array}{l}\text { Enhanced GHG emissions can } \\
\text { occur when grassland or } \\
\text { wetlands are converted, } \\
\text { enhanced GHG due to } \\
\text { increased fertilizing (esp. } \mathrm{N}_{2} \mathrm{O} \text { ) }\end{array}$ & $\begin{array}{l}\text { Can act as a storage for GHG } \\
\text { by humus and underground } \\
\text { biomass accumulation, wetland } \\
\text { or forest conversion for } \\
\text { coppices enhances GHG }\end{array}$ \\
\hline \multirow[t]{2}{*}{$\begin{array}{l}\text { Nutrient and humus } \\
\text { balance of soils }\end{array}$} & Nutrient input & $\begin{array}{l}\text { High nutrient and biocide } \\
\text { applications }\end{array}$ & $\begin{array}{l}\text { Can reduce nutrient input and } \\
\text { biocides compared to annual } \\
\text { crops, increased input when } \\
\text { extensive uses like grassland or } \\
\text { hedges are converted to } \\
\text { coppices }\end{array}$ \\
\hline & Nutrient leaching & $\begin{array}{l}\text { High nutrient leaching rates, } \\
\text { especially when inappropriate } \\
\text { management practices are } \\
\text { applied }\end{array}$ & $\begin{array}{l}\text { Can reduce nutrient leakage } \\
\text { compared to annual crops }\end{array}$ \\
\hline $\begin{array}{l}\text { Mitigating soil } \\
\text { erosion }\end{array}$ & Soil coverage & $\begin{array}{l}\text { High water and wind erosion in } \\
\text { periods without vegetation } \\
\text { cover }\end{array}$ & $\begin{array}{l}\text { Permanent vegetation cover } \\
\text { lowers wind and water erosion, } \\
\text { acting as shelterbelts, reduced } \\
\text { and slowed water runoff } \\
\text { reduces soil erosion }\end{array}$ \\
\hline
\end{tabular}




\begin{tabular}{|c|c|c|c|}
\hline Water retention & Water runoff & $\begin{array}{l}\text { Increased water runoff } \\
\text { especially in vegetation free } \\
\text { periods, maize has rather poor } \\
\text { water retention rates }\end{array}$ & $\begin{array}{l}\text { Lowered water runoff, } \\
\text { interception rate increases } \\
\text { when trees or shrubs are in } \\
\text { older/higher stages }\end{array}$ \\
\hline $\begin{array}{l}\text { Self-purification of } \\
\text { water }\end{array}$ & $\begin{array}{l}\text { Biocide loads in } \\
\text { water, efforts for } \\
\text { water purification } \\
\text { to gain water }\end{array}$ & $\begin{array}{l}\text { High nutrient leakage leads to } \\
\text { rising and more costly efforts to } \\
\text { purify water, water qualities are } \\
\text { often not sufficient to meet } \\
\text { legal minimum standards }\end{array}$ & $\begin{array}{l}\text { Low leakage of nutrients, } \\
\text { higher purification rates than } \\
\text { annual crops lead to lower } \\
\text { loads with nutrients and } \\
\text { biocides in waters }\end{array}$ \\
\hline $\begin{array}{l}\text { Groundwater } \\
\text { protection and } \\
\text { recharge }\end{array}$ & Water levels & $\begin{array}{l}\text { Higher recharge rates, however } \\
\text { water quality is lower due to } \\
\text { nutrient leakage and nitrogen } \\
\text { inputs (see above) }\end{array}$ & $\begin{array}{l}\text { Lower recharge due to } \\
\text { perennial cover, dense } \\
\text { plantation and interception } \\
\text { compared with annuals crops, } \\
\text { water demand of woody plant } \\
\text { is higher due to higher } \\
\text { transpiration, groundwater } \\
\text { levels might be lowered }\end{array}$ \\
\hline $\begin{array}{l}\text { Regulation of pest } \\
\text { populations }\end{array}$ & $\begin{array}{l}\text { Resistance of } \\
\text { plants, necessity to } \\
\text { utilize biocides }\end{array}$ & $\begin{array}{l}\text { Higher pest risks, enhanced } \\
\text { spreading of pest insects like } \\
\text { European Corn Borer (Ostrinia } \\
\text { nubilalis) and Western Corn } \\
\text { Rootworm (Diabrotica } \\
\text { virgifera virgifera) in maize } \\
\text { demand biocide application, } \\
\text { trends to the introduction of } \\
\text { genetically modified crops }\end{array}$ & $\begin{array}{l}\text { Better stability and resilience } \\
\text { against pests, however rust } \\
\text { fungi (Melampsora) and leaf } \\
\text { beetles (Melasoma populi) can } \\
\text { be a risk }\end{array}$ \\
\hline Pollination & $\begin{array}{l}\text { Populations of } \\
\text { pollinating insects }\end{array}$ & $\begin{array}{l}\text { Wind pollination of maize, } \\
\text { does not provide nectar, } \\
\text { reduced supply of nectar due to } \\
\text { reduced cultivation of clover, } \\
\text { peas and other flowering } \\
\text { plants; little accompanying } \\
\text { vegetation }\end{array}$ & $\begin{array}{l}\text { The trees are usually harvested } \\
\text { before they reach relevant age, } \\
\text { few flowering species in the } \\
\text { accompanying vegetation; } \\
\text { willow species might provide } \\
\text { nectar for insects }\end{array}$ \\
\hline \multirow[t]{3}{*}{ Biodiversity } & $\begin{array}{l}\text { Crop species, } \\
\text { structures, } \\
\text { management }\end{array}$ & $\begin{array}{l}\text { Few species, intensive } \\
\text { management, genetically } \\
\text { modified species, rather early } \\
\text { date of harvest }\end{array}$ & $\begin{array}{l}\text { Few high yield species, } \\
\text { genetically modified species, } \\
\text { rather uniform structures, } \\
\text { however longer rotation periods } \\
\text { around 2-5 years, few } \\
\text { accompanying species }\end{array}$ \\
\hline & Bird species & $\begin{array}{l}\text { Earlier harvesting before seed } \\
\text { ripeness leads to lacks of } \\
\text { fodder for corn-feeding birds in } \\
\text { autumn (e.g. resting Nordic } \\
\text { geese), few habitats for ground- } \\
\text { nesting birds needing lower } \\
\text { management intensities, e.g. } \\
\text { for partridge, lapwing, sky-lark }\end{array}$ & $\begin{array}{l}\text { Provision of habitats for birds } \\
\text { depending on hedges and shrub } \\
\text { vegetation, conversion of } \\
\text { agricultural land leads to } \\
\text { habitat loss for ground nesting } \\
\text { birds }\end{array}$ \\
\hline & $\begin{array}{l}\text { Crop-related } \\
\text { biodiversity } \\
\text { (except birds) }\end{array}$ & $\begin{array}{l}\text { Poor wild flora and fauna due } \\
\text { to biocide use and tilling } \\
\text { operations, habitat conditions } \\
\text { are favorable only in less } \\
\text { intensive used fields }\end{array}$ & $\begin{array}{l}\text { Increase in biodiversity } \\
\text { (depending on the previous } \\
\text { crops and intensities), can } \\
\text { provide habitat connectivity, } \\
\text { new structures in agricultural } \\
\text { land, some accompanying } \\
\text { vegetation, but mainly } \\
\text { ubiquists; loss of species and } \\
\text { richness of structures when } \\
\text { extensively used and fallow } \\
\text { lands are converted to coppices }\end{array}$ \\
\hline
\end{tabular}




\begin{tabular}{|l|l|l|l|}
\hline $\begin{array}{l}\text { Socio-cultural } \\
\text { services }\end{array}$ & $\begin{array}{l}\text { Food-feed -fuel } \\
\text { discussion }\end{array}$ & $\begin{array}{l}\text { Food crops used for energy } \\
\text { production is seen critical from } \\
\text { ethical point of view, especially } \\
\text { when cereals are used as fuel } \\
\text { (rising food prices, famine and } \\
\text { starvation is a major issue in } \\
\text { many developing countries) }\end{array}$ & $\begin{array}{l}\text { No direct food-feed-fuel } \\
\text { discussion, however indirect } \\
\text { effects: Agricultural land is } \\
\text { needed for coppices that is no } \\
\text { longer available for food } \\
\text { production }\end{array}$ \\
\cline { 2 - 4 } & Diversity of life & $\begin{array}{l}\text { Few species, genetically } \\
\text { modified plants }\end{array}$ & $\begin{array}{l}\text { Few species, sometimes } \\
\text { genetically modified plants }\end{array}$ \\
\cline { 2 - 5 } & $\begin{array}{l}\text { Cultural heritage } \\
\text { and reflecting } \\
\text { traditions }\end{array}$ & $\begin{array}{l}\text { Decline of traditional land use } \\
\text { systems, selection of few crops, } \\
\text { uniformity of landscapes }\end{array}$ & $\begin{array}{l}\text { New landscape elements, can } \\
\text { reflect and pick up e.g. } \\
\text { traditional willow cultivation } \\
\text { (for provisioning raw material } \\
\text { for basket weaving) in a new } \\
\text { context of energy production }\end{array}$ \\
\cline { 2 - 5 } & $\begin{array}{l}\text { Objects for } \\
\text { research and } \\
\text { teaching }\end{array}$ & $\begin{array}{l}\text { Focus on few crops reduces } \\
\text { diversity, e.g. for bio-indication }\end{array}$ & $\begin{array}{l}\text { New research opportunities } \\
\text { with a rather new land use form }\end{array}$ \\
\hline Landscape aesthetics & $\begin{array}{l}\text { Richness in } \\
\text { landscape } \\
\text { structures }\end{array}$ & $\begin{array}{l}\text { Mainly cultivated in uniform } \\
\text { blocks, however different } \\
\text { appearance during the year }\end{array}$ & $\begin{array}{l}\text { Can increase richness of } \\
\text { structures in agricultural } \\
\text { landscapes }\end{array}$ \\
\cline { 2 - 5 } & $\begin{array}{l}\text { Visibility of } \\
\text { landmarks }\end{array}$ & $\begin{array}{l}\text { During summer months, } \\
\text { visibility can be blocked, high } \\
\text { visibility in winter months }\end{array}$ & $\begin{array}{l}\text { Coppice blocks visibility } \\
\text { permanently except for a short } \\
\text { period after cutting }\end{array}$ \\
\hline
\end{tabular}

Summarizing the most important results, it can be stated, that on one hand, the need of plant biomass offers new opportunities for agriculture and forestry. Mixed cultures, perennial crops, and agro-forestry systems outmatch agro-ecosystems in delivering services, e.g. providing habitats, slowing down run-off, recycling wastewater etc. as well as restore services on degraded land (Rode et al. 2005). Coppice forests dedicated to energy production can increase structures in intensively used agricultural areas and provide habitats for nesting birds (Göransson 1994, Liesebach \& Mulsow 2003), and even red list species (Burger 2005), increase scenic qualities and contribute to a green infrastructure (Londo et al. 2004). A new market for thermal utilization of forest residues, roadside vegetation and landscape management actions can emerge (e.g. Wachendorf et al. 2008). Such biomass production allows minimizing inputs like fertilizing, tilling or using herbicides.

Negative impacts are seen in shortened rotation periods on agricultural land and in forests, unification of crops and vast monocultures (SRU 2007). An extreme expression of such monocultures is the "self rotation" of maize (for the Federal State of Saxony in 2008 this rate was about $9 \%$ of the total maize cultivation area). In many cases, plants with a high demand for nitrogen inputs and nitrogen spillovers are favoured at the moment, especially maize (Deutsches Maiskomitee 2010), which leads to an increased application of mineral fertilizers on many sites (NABU 2005). Cultivation of water demanding crops is also seen as a problem, especially when looking at climate change corresponding with the decline of water availability (Hall et al. 1996; Heitmann et al. 2000). Erosion processes occur due to the extraction of organic material on vulnerable sites e.g. slopes (Rode et al. 2005). The use of residues partially competes with nutrient cycling and humus formation (Vetter 2001) as well as regulating services such as carbon storage and water retention (NABU 2005). Also competition between energy or food production as well as competition 
with raw materials for industrial needs (e.g. pulpwood) can be observed (Bringezu \& Steger 2005).

The extraction of all by-materials of the harvest can reduce soil fertility (DBFZ 2009). It can be observed that meadows are converted into arable fields for the growth of energy plants (NABU 2007). An increased demand for bio-energy might lead to an unrestricted cultivation of genetically modified organisms, since concerns for food safety are not important in energetic use (NABU 2005). Energy crop production can interfere with goals of nature conservation. Payments for habitat or landscape management might get less attractive for farmers who can gain more revenue by cultivating energy crops (Bardt 2008). In consequence, a loss of biodiversity due to more intense land use is expected.

Also in forests, a more intense use of residues may have impacts on soil fertility as well as on habitats. Short rotation coppices can threat the integrity of wetlands due to their water demand (EEA 2006). Both the cultivation of energy crops or coppice can have negative impacts on scenic qualities (NABU 2005).

The intensive maize production leads to an increase of wild boar population (Sus scrofa) (Petrak 2009) that can damage crops, ground-nesting birds and spread diseases. Finally, the political goal of reducing $\mathrm{CO}_{2}$ emissions is failing due to changes in ecosystems, e.g. by destroying wetlands or forests acting as carbon storage or carbon sinks for the production of biomass or a more intense land use that demand for more energy input (NABU 2005).

\section{REGULATORY MEASURES FOR THE GROWTH OF ENERGY CROPS IN SPATIAL PLANNING - THE CASE OF GERMANY}

There are several international, national and federal regulations in place to manage and protect landscapes. In this chapter, some selected protection categories, laws and planning instruments are analyzed concerning their regulation effect on energy crop production. First of all, it has to be stated, that the holistic concept of Ecosystem Services is not (yet) applied in legislative or planning. Some existing legislation can be interpreted as implying ecosystem services, but it not named as such (Haslett et al. 2010). The question arises, whether these regulations actually influence on-site cultivation of energy crops to secure or improve the provisioning of ecosystem services significantly. In the following section, we analyzed a number of laws, planning and protection categories.

\section{Protected Areas}

A number of legal categories of nature and landscape protection on national and European levels can protect biodiversity by regulating the cultivation of biomass for energy production (BMELV \& BMU 2009). The Federal Nature Conservation Act (Federal Law Gazette I 2009, p. 2542) and the Nature Conservation Acts of the German states ("Bundesländer") allow authorities to designate protected areas in places with high biological values. The obligation for the designation of protected areas especially arises from the European Habitats Directive (92/43/EEC, Official Journal EC 1992, L 206/7) and the European Birds Directive (79/409/EEC, Official Journal EC 1979, L 103/1), i. e. the Natura 2000 sites. Restrictions are made by regulations that have to be set up for each protected area. Therefore, agricultural biomass production can be limited in Natura 2000 sites where binding guidelines exist. In these areas any deterioration is prohibited and management action plans and impact assessments are required (cf. Article 6 Habitats Directive and Sections 32 Fet seg. (Federal Nature Conservation Act). In addition, the German Federal Nature Conservation Act protects a number of biotopes directly by law 
(so-called biotopes protected by law). However, ecosystem services have not been picked out as a central topic so far.

\section{Regulatory Law}

Basic administrative standards in Germany for cultivation of biomass are set in nature conservation laws as well as in soil conservation laws, but also in fertilizing and plant protection laws. The primary goal is to secure "good management practices", which are required according to the Federal Nature Conservation and Soil Conservation Acts. In detail, these laws demand adapted soil tillage, boost of biological activity, avoidance of soil compaction, and restrict the conversion of grassland to arable fields in sensitive areas. Besides these relatively vague restrictions, agriculture and forestry are to a large extent privileged (Ekardt et al. 2008). Agricultural and forest management activities are not considered an interference with nature and landscape, neither is the extraction and marketing of natural products, as long as "good management principles" are applied (cf. Section 14 para. 2 and Section 44 para. 4 sent. 1 Federal Nature Conservation Act). There are only certain restrictions in concern of the species listed in Annex IV of the Habitats Directive and European bird species (cf. Section 44 para. 4 sent. 2 Federal Nature Conservation Act). Accordingly, deliberate catching or killing of these species as well as disturbance is forbidden, as well as disturbance or destruction of their habitats (Section 44 para. 1 Federal Nature Conservation Act). Looking at the provided legislation standards, these regulations and their actual effectiveness have to be scoped in detail.

\section{Planning instruments and environmental assessment}

Due to the increased production of biomass, growing pressures and competition among various options of land uses are expected. Therefore it is a necessity to find a fair balance between these demands in formal and informal planning procedures.

The effects of a large scale energy crop production have to be considered in spatial planning. For instance, the extension of agricultural land use in ecological sensitive areas can be restricted in regional plans by the designation of priority areas or reserved-function areas for nature conservation (cf. Section 8 para. 7 Federal Spatial Planning Act). Furthermore, agricultural use in such areas could be restricted (SRU 2007). However, the influence of spatial planning on the production of biomass for energy purposes is limited. In principle, regional plans in Germany are only binding against authorities (cf. Section 4 Federal Spatial Planning Act). In contrast to the construction of buildings and structures, changes in the use of existing agricultural areas do not require administrative permissions (SRU 2007). Therefore, the designations of the spatial plans are normally not binding for individual farmers.

The situation concerning urban land use planning is similar. Exceptionally, local development plans can influence agricultural land use, e.g. by the designation of restrictions for farming, even if "good practice" standards are met (cf. Section 9 para. 1 No. 20 Federal Building Code; SRU 2007).

In sectoral planning, landscape planning on its different levels is the most important planning instrument and a key for nature protection issues (Janssen \& Albrecht 2008). Landscape planning has to assess all physical aspects of landscape and ecosystem functioning as well as the landscape scenery in a region and thus includes considering the cultivation of biomass for energy purposes (BDLA 2005). Hence it can have spatial regulating effects on the cultivation of energy crops at least to some extent (Janssen \& Albrecht 2008). 
Environmental Impact Assessment (EIA) focuses on projects, and thus it has only indirect influence on the cultivation of energy crops, e.g. on the construction of biogas plants. In contrast, Strategic Environmental Assessment (SEA) is applied to assess environmental impacts that arise from planning and certain programs, e.g. spatial plans and landscape plans. However, the information in the plans concerning agricultural land use is often insufficient. A formal instrument of agricultural sectoral planning does not exist in Germany.

\section{Public funding and certification}

The scale of biomass use for producing renewable energy is mainly dependent on economic conditions, e.g. energy prices in comparison to markets for food or livestock feed (BMELV \& BMU 2009). Therefore, subsidies have pivotal impact. The revenue gained determines if an area serves for food or energy and if farmers also consider nature conservation by contract on their property. With higher revenues gained by unrestricted food or energy crop production compared to additional payments for nature protection by contract programs, farmers might cease these programs (Ginzky 2008). A closer look on the subsidy and financial support programs is necessary to understand their impact on ecosystem services.

The most important tool is the Common Agricultural Policy of the European Union with its various grants and funding programs. According to a simple payment scheme designated by the EC Regulation No. 1782/2003 (Official Journal EU 2003, L 270/1) farmers get funding no matter if food or energy crops are grown. Art. 88 EC Regulation 1782/2003 subsidizing directly biomass production for energy purposes. European agricultural funding demands cross-compliance with other regulations, e.g. abidance by environmental standards (see Art. 4 \& 5, EC Regulation 1782/2003). However, there are no favoured area settings or a sophisticated economic stimulation for energy crops considering spatial aspects.

The cultivation of energy crops in Germany is boosted by the Renewable Energy Act which sets a fixed price to be paid for electricity produced from renewable sources of energy delivered to the grid. Based on this act, the so-called "Biomass-ElectricitySustainability Ordinance" (In German: "Biomassestrom-Nachhaltigkeitsverordnung", Federal Law Gazette I 2009, p. 2174) was adopted in July 2009, which names criteria for growing biomass. This ordinance has delivered important stimuli from the European Directive 2009/28/EC on the promotion of the use of energy from renewable sources ("Renewable Energy Directive", Official Journal EU 2009, L 140/16). The subsequent "Biofuel Sustainability Ordinance” (in German: „Biokraftstoff-Nachhaltigkeitsverordnung“, Federal Law Gazette I 2009, p. 3182) has a largely similar content. It was passed end of September 2009. The compliance of criteria set by this ordinance is a requirement, that biofuels derived from biomass can be counted to the compulsory blending quota according to the "Biofuel Quota Act" (In German: "Biokraftstoffgesetz", Federal Law Gazette I 2006, p. 3180). It therefore qualifies for tax reductions according to the Energy Taxation Act (In German: "Energiesteuergesetz", Federal Law Gazette I 2006, p. 1534) (Ginzky 2008, Lee et al. 2008). Both the Biomass-Electricity-Sustainability Ordinance and the Biofuel Sustainability Ordinance name criteria such as prohibiting the cultivation of energy crops in areas of high nature protection value. Compliance to this should be proven by a certificate. While these new sustainability criteria for biomass production are generally favourable, the impact of energy crops on the environment cannot be generalized and needs to be subject to a closer, more detailed study (Lee et al. 2008), considering all aspects of ecosystem services. 
German National Strategy on Biological Diversity, the Strategy on Agro-Biodiversity (BMELV 2009) and the national Biomass Action Plan (BMELV \& BMU 2009) point out, that the cultivation of energy crops has to be sustainable. They demand the development of international standards and certification systems and considering "good management standards" (BMELV 2009; BMU 2007; BMELV \& BMU 2009). Therefore sustainability on all levels as well as baselines for certification schemes are of a great importance.

\section{Case Study Moritzburg Small-Hill Landscape}

The Moritzburg Small-Hill Landscape is situated $10 \mathrm{~km}$ north of the city of Dresden (Saxony, Germany). The geomorphology and relief of the study area are very characteristic and singular even from a European point of view: Small-scaled pattern of hills, low ridges with out-jetting rocks and flat hollows. The bedrock is dominated by monzonits, but also granodiorite, gneiss, pleistocene loams, sands and gravel occur. The soils at the hills are characterised by dystric cambisols. Loamy and sandy stagnosols and cambic stagnosols are in the hollows. On the tops of the hills, skeletic leptosols can be found. The geomorphologic basic pattern causes the high diversity of soil, water, and climatic conditions, which is responsible for the present heterogeneous vegetation cover, flora, fauna and land use. Arable fields dominate on slopes, and grassland is related esp. to the moist hollows. Woods occur mainly on the crests of the rocky and stony hills. An effective agricultural production is restricted by the complicated natural site conditions. Land improvements (esp. drainage) were tested to diminish this natural heterogeneity but not with much success. The result is a rich-structured rural landscape with a notably high biodiversity and varied scenery. The area is particularly rich in species adapted to less intensive agriculture, e.g. rare arable weeds, plants of field margins, edges and small coppices; birds breeding in hedges, woods, grassland and arable fields; small mammals, amphibians, reptiles and many insect species (Schrack 2001). The Moritzburg Small-Hill Landscape provides many ecosystem services like habitat function, water balance, and recreation services in the vicinity of the Dresden urban agglomeration (Bastian \& Röder 1998).

For the Moritzburg Small-Hill Landscape expert based scenario studies were carried out by Bastian et al. (2006) several years ago to analyze effects of three different possible land use options on selected ecosystem functions and services. The chosen scenarios were:

Increased cultivation of energy crops (rape, maize) and short rotation coppices for wood chips (willow, poplar).

\section{Abandonment of livestock farming, and agriculture with a strong focus on nature conservation}

The energy crop scenario developed by Bastian et al (2006) described an intensification of grassland for fodder to compensate losses on parcels, which are cultivated with energy crops. The distribution of crops would change and shift towards rape and maize on fertile sites. Short rotation coppice could be established in moist places replacing grassland. This scenario leads to a reduction of plant species and communities of moist and wet meadows. On one hand, wood plantations would increase habitat qualities for certain species dependant on hedges and forests, on the other hand, habitats for field species would diminish. Maize and rape are usually poor in numbers of breeding birds (George 2004), so in general, a loss in species is to be expected in this scenario. Maize fields are prone to erosion. For landscape aesthetics, the increase of cultivating energy crops has a negative impact since views might get lost by tall and dense vegetation including short rotation coppices. Economic revenues gained from farming activities were analyzed in detail. 
Compared to the other scenarios developed, the energy crop production option leads to the highest income. However, the revenues gained in this scenario are strongly influenced by the common agricultural policy and subsidies paid (Bastian et al. 2006).

Recently, just outside the study area in a commercial zone, a 2.1 MW biogas power plant was built operating on silage maize. The power plant has an annual demand of $9.500 \mathrm{t}$ of maize, which requests an overall acreage of 200-250 ha (DREWAG 2010). Contracts for supplying the plant were made with an agricultural co-operative operating in the Moritzburg Small-Hill Landscape. With around 2,000 ha of arable land in the study area, more than $10 \%$ of it has to be used exclusively for supplying the biogas plant. In 2008, before the biogas plant was established, already $24 \%$ of the arable fields were used to grow maize, mainly fodder for the co-operatives livestock (Agrargenossenschaft Radeburg 2010) and was increased up to over 30\% in 2010 (Oertel, verbal communication 2011). By looking at these developments, the biomass production scenario has become reality with the exception of short rotation coppices, which have not yet been established. On-site surveys and monitoring of nesting birds indicate a decline compared with the mid-1990s, when the production on the fields was intensified and the portion of maize steadily increased (Arnold et al. 2008; Fachgruppe Ornithologie Großdittmannsdorf 2008).

The question therefore arises, whether these possible impacts of the stock for biogas plants are considered when such plants are planned and built. The approval process of the biogas plant next to the protected area considered a number of laws and regulations, the Federal Immission Control Act (In German: "Bundesimmissionschutzgesetz", Federal LaW Gazette I 2002, p. 3830) being the most important one. However, the approval process for the plant does not consider the impact of growing feedstock on ecosystem services in the study area where the raw material is produced. It only considers on-site impacts by operation actions of the biogas power plant in the commercial zone. To conclude, the regulation of supply production, especially the mitigation of monocultures and highintensive growing forms has to be regulated on the adequate spatial level where biogas plants are built.

Looking at the study area, it is covered by several categories of small- and large-scale conservation categories on regional (Saxony), national (Germany) and international (EU) levels. There is a landscape protection area (German legal category "Landschaftsschutzgebiet") that is a defined site placed under statutory landscape conservation because of its diversity, distinctive character or beauty, its scientific or historical importance, or its particular significance in terms of nature protection, the natural balance, or recreation (Section 26 para. 1 Federal Nature Conservation Act). Certain economic activities, such as agriculture and forestry, are permitted in principle. The ordinance for this landscape protection area (3,650 ha) in 1998 aimed for a harmonic co-existence of landscape use as well as to maintain the rich biodiversity and to provide attractive sceneries for nature based recreation close to the city.

Valuable small ponds, swamps, meadows, dry meadows are protected as natural monuments with spatial extent (German legal category „Naturdenkmal”). This category is defined as "a natural feature $[<5$ ha] which has been listed for protection [...] either because it is of particular interest in terms of scientific value, natural history or local studies, or because of its rarity, distinctive character or beauty. The immediate surroundings may also be covered by the statutory order" (Section 28 para. 1 Federal Nature Conservation Act). Some biotopes of the study area are automatically protected by law without any specific designation, e.g. several types of forests, water, sparse orchards, oligotrophic and wet grassland, and dry-stone walls (cf. Section 30 Federal Nature Conservation Act). 
Finally, parts of the area belong to the network of Natura 2000 sites. The Special Protected Area (SPA) „Moritzburger Kleinkuppenlandschaft“ (Moritzburg Small-Hill Landscape) is 3,150 ha in size. Species to be protected are: Hobby (Falco subbuteo), Northern Lapwing (Vanellus vanellus), Ortolan Bunting (Emberiza hortulana), Honey Buzzard (Pernis apivorus), Corn Bunting (Emberiza calandra), Red-Backed Shrike (Lanius collurio), Northern Grey Shrike (Lanius excubitor), Western Marsh-Harrier (Circus aeruginosus), Black Kite (Milvus migrans), Red Kite (Milvus milvus), Barred Warbler (Sylvia nisoria) and Corn Crake (Crex crex).

The Site of Community Importance (SCI) "Promnitz und Kleinkuppenlandschaft bei Bärnsdorf" (Promnitz rivulet and small hill area near the village of Bärnsdorf) covers 294 ha. Along the Promnitz rivulet various grassland communities are occurring as well as fallow land, perennial herb communities and small ponds. Otter (Lutra lutra) and especially the Dusky Large Blue butterfly (Maculinea nausithous; syn. Glaucopsyche nausithous) are animals of European Community interest, the latter with one of its most important sites in Germany and Europe.

Administrative laws do not influence the selection of crops at all in the study area, and forestry and agriculture activities are allowed to a large extent. The only limitation is an interdiction of cultivating genetically modified maize in the SCI Promnitz. For Saxony and therefore also for the study area, there is a promotion program for small scale nature conservation focussing on breeding habitats and protection of ground-nesting birds. However, for farmers, energy crop production based on maize and market crops favoured by the Common Agricultural Policy (CAP) are the ones to gain the highest revenues in the study area even when high community interest exists to provide also other ecosystem services.

\section{CONCLUSIONS AND OUTLOOK}

With the increased growth of energy crops a number of chances are envisaged, i.e. to generate incomes, prevent risks, use natural potentials and maintain all landscape functions to support a sustainable development of the region. Drawn from the literature review, from the Moritzburg case study and own experience it can be demonstrated that biomass production has various effects on ecosystem services. An increased unselective and unregulated cultivation of energy crops has negative impacts on many ecosystem services. Currently, laws, incentives and funding do not properly balance and regulate the cultivation of energy crops, and they do not consider ecosystem services adequately. It could be demonstrated both by the literature review and the case study in the Moritzburg Small-Hill Landscape, that monocultures of maize are favoured in most cases, regardless of other (e.g. environmental) interests and despite of negative impacts on ecosystem services.

Coppice as a perennial form of land use can enhance the provisioning of ecosystem services in many cases, if the cultivation is restricted to formerly intensive used agricultural land. It can have negative impact especially on biodiversity when replacing high value grasslands. An increased use of landscape management materials derived from hedges and high value grassland would mainly have positive effects on many ecosystem services. However, it seems not very likely to use it to larger extents since revenues gained are very low. The existing additional funding for these sources does not promote its use (Peters 2009, Stegner 2010). As we could show, the existing regulatory measures include some restrictions and offer the possibility to regulate the development of energy crop cultivation. These potentials are not sufficiently implemented in practice, yet, and thus they only have 
little effects on the actual land use. There is a need to have a more detailed analysis and possibly specification and enhancement of regulatory measures and subsidy practices for the cultivation of energy crops, since the existing policies have no substantial effects on maintaining all ecosystem services.

Looking at the broad concept of Ecosystem Services, cultivation of biomass for energy purposes and its guiding regulative measures like laws and subsidies should be optimized by including various aspects, in particular the integration of socio-economic as well as ecological assessments. Spatial recommendations for priority areas for cultivating energy crops seem to be evident as well as regional target-oriented recommendations for their cultivation. Thus, suitable spatial planning instruments are necessary to direct energy crop cultivation, in order to reduce impacts on ecosystems and to define Safe Minimum Standards. Furthermore, the case study demonstrates that there is not only a need to work on enhancing spatial strategies and regulatory measures but also on subsidiary practices and the financial framework.

Given these high priority political goals and looking at findings from the Moritzburg case study and its impacts on ecosystem services and Biological diversity, more than only few selected ecosystem services have to be taken into consideration to get a broad view. Also decision making of farmers should be analyzed in detail, especially in considering crop selection and the actual importance of various regulatory measures. To what extent do different laws, protection categories and subsidies influence and regulate energy crop production, and how ecosystem services are affected? In which way energy crop production can be influenced to meet Safe Minimum Standards for all ecosystem services, and which tools are appropriate and gain wide acceptance among stakeholders? To answer these questions, a research project is running under the lead of the Leibniz Institute of Ecological Urban and Regional Development to work collaboratively with energy crop farmers, the International Meeting Centre of St. Marienthal, the Federal State of Saxony nature conservation authorities, and the Leibniz Centre for Agricultural Landscape Research (ZALF Müncheberg). The focus lies on testing and evaluating regulatory measures for biomass production by using the concept of Ecosystem Services.

\section{REFERENCES}

Agrargenossenschaft Radeburg (2010). Pflanzenproduktion. Retrieved 11.7.2011, from: http://www.agrar genossenschaft-radeburg.de/pflanzen.html

Arnold, K.P., Oertel, H. \& Umlauf, B. (2008). Aktuelle Entwicklungen von Landwirtschaft und Naturschutz im Landschaftsschutzgebiet "Moritzburger Kleinkuppenlandschaft“ Denkschrift „Landwirtschaft und Naturschutz“ 2007. Retrieved 11.7.2011, from http://www.fggrossdittmanns dorf.de/texte/denkschrift_2008_landwirtschaft_und_natur schutz.pdf

Bardt, H. (2008). Entwicklungen und Nutzungskonkurrenz bei der Verwendung von Biomasse in Deutschland. IW-Trends -Institut der Deutschen Wirtschaft Köln. 35(1).

Bastian, O., Corti, C. \& Lebboroni, M. (2007). Determining Environmental Minimum Requirements for functions provided by agro-ecosystems. Agronon. Sustain. Dev. 27:1-13.

Bastian, O., Lütz, M., Röder, M. \& Syrbe, R.-U. (2006). The assessment of landscape scenarios with regard to landscape functions. In: Meyer, B.C. (Ed.). Sustainable land use in intensively used agricultural regions. pp. 15-22. Landscape Europe, Alterra Report No. 1338, Wageningen. 
Bastian, O., Röder, M. (1999). Analyse und Bewertung anthropogen bedingter Landschaftsveränderungen - anhand von zwei Beispielsgebieten des sächsischen Hügellandes. In: Haase, G. (Ed.). Beiträge zur Landschaftsanalyse und Landschaftsdiagnose. Abhandl. Sächs. Akad. d. Wiss. zu Leipzig, math.-nat. Klasse, vol. 59(1):75-149.

Bastian, O., Schreiber, K.-F. (1999). Analyse und ökologische Bewertung der Landschaft. Spektrum Heidelberg - Berlin. 2. ed., 564 pp. (1. ed. 1994).

BDLA (Bund Deutscher Landschaftsarchitekten) (2005). Die kommunale Landschaftsplanung - ein Planungsinstrument der Zukunft. Freising

Börjesson, P. (1999A). Environmental effects of energy crop production - Part I: Identification and quantification. Biomass and Bioenergy 16, 137-154.

Börjesson, P. (1999B). Environmental effects of energy crop production - Part II: Economic valuation. Biomass and Bioenergy 16, 155-170.

BMELV (2009). Agrobiodiversität erhalten, Potenziale der Land-, Forst- und Fischereiwirtschaft erschließen und nachhaltig nutzen. Eine Strategie des BMELV für die Erhaltung und nachhaltige Nutzung der biologischen Vielfalt für die Ernährung, Land-, Forst- und Fischereiwirtschaft. Berlin.

BMELV, BMU (2009). Nationaler Biomasseaktionsplan für Deutschland. Beitrag der Biomasse für eine nachhaltige Energieversorgung. Berlin.

BMU (Federal Ministry for the Environment, Nature Conservation and Nuclear Safety) (2007). National Strategy on Biological Diversity. Berlin

Bringezu, S., Steger, S. (2005). Biofuels and competition for global land use. Global Issue Papers 20, Heinrich Böll Stiftung, Berlin.

Bruell, A. (2007). Complementary biomass strategy - applying the ecosystem services concept in sustainable landscape management. In: Bunce, R.G.H., Jongman, R.H.G., Hojas, L. \& Weel, S. (Eds.). 25 years of Landscape Ecology: Scientific Principles in Practice. (404-408 pp.). Proc. 7th IALE World Congress 8-13 July Wageningen, The Netherlands

Burger, F. (2005). Energiewälder und Ökologie. LWFaktuell 48:26-27.

Cherubini, F., Stromman, A.H. (2010). Life cycle assessment of bioenergy systems: State of the art and future challenges. Bioresource Technology, in press

Ciriacy-wantrup, S. (1952). Resource conservation economics and politics. Univ. of California, Div. of Agriculture Sciences. Berkeley, Los Angeles.

Commission of the european UNION (1999). Directions towards sustainable agriculture. Communication of the Commission of the European Communities, COM (1999) 22 final, in reference to Regulation (EC) No 1259/1999 (common rules for direct support schemes), Article 2, Brussels.

Commission of the european communities (2007). Renewable Energy Road Map Renewable energies in the 21st century: building a more sustainable future. Communication from the Commission to the Council and the European Parliament: Brussels.

Costanza, R. (1991). Ecological Economics: the science and management of sustainability. Columbia University Press, $525 \mathrm{pp}$.

Costanza, R., D’arge, R., DE Groot, R., Farber, S., Grasso, M., Hannon, B., Limburg, K., Naeem, S., O’Neill, R., Paruelo, J., Raskin, R., Sutton, P. \& Van Den Belt, M. (1997). The value of the world's ecosystem services and natural capital. Nature 387:253-260. 
DBFZ (German Biomass Research Centre) (2009). Identifizierung strategischer Hemmnisse und Entwicklung von Lösungsansätzen zur Reduzierung der Nutzungskonkurrenzen beim weiteren Ausbau der energetischen Biomassenutzung. 1. prelim. Report, Leipzig.

DE Groot, R., Wilson, M. \& Boumans, R. (2002). A typology for description, classification and valuation of ecosystem functions, goods and services. Environmental Economics 41:393-408.

Deutsches maiskomitee (2010). Maisanbaufläche in Deutschland in ha, 2009 und 2010 (vorläufig) nach Bundesländern und Nutzungsrichtung in ha. Bonn: DMK. Retrieved 10.6 2010, from http://www.maiskomitee.de/web/intranet/news.aspx?news=69004569-424f4edf-b6b0-7c45995cbeee

Drewag (2010). Zukunftsenergie - Was macht die Drewag? Nonstop . Kundenmagazin 1, Dresden. Retrieved 10.6. 2010, from http://www.drewag.de/media/pdf/de/dg_kunden magazin_1_2010/06-dresden-2010.pdf

EEA (European Environment Agency) (2006). How much bioenergy can Europe produce without harming the environment? Luxembourg: Office for Official Publications of the European Communities. EEA Report 7/2006.

Ekardt, F., Heym, A. \& Seidel, J. (2008). Die Privilegierung der Landwirtschaft im Umweltrecht. ZUR (Zeitschrift für Umweltrecht)19:169-177.

Ericsson, K., Rosenqvist, H. \& Nilsson, L. J. (2009). Energy crop production costs in the EU. Biomass and Bioenergy 33: 1577-1586.

European commission (1997). Energy for the Future: Renewable Sources of Energy White Paper for a Community Strategy and Action Plan". Communication from the Commission, Brussels.

European commission - OFFICE FOR OFFICIAL PUBLICATIONS OF THE EUROPEAN COMMUNITIES (2004). Energy: Yearly statistics - Data 2002, Brussels.

George, K. (2004). Veränderungen der ostdeutschen Agrarlandschaft und ihrer Vogelwelt. APUS, Beiträge zur Avifauna Sachsen-Anhalts, Halle/S.

Ginzky, H. (2008). Der Anbau nachwachsender Rohstoffe aus Sicht des Bodenschutzes. Gegenwärtige Rechtslage und Änderungsbedarf. ZUR (Zeitschrift für Umweltrecht) 19:188194.

Göransson, G. (1994). Bird fauna of cultivated energy shrub forests at different height. Biomass and Bioenergy 6: 49-52.

Greiff, K.B., Weber-blaschke, G., Faulstich, M. \& Von Haaren, C. (2010). Förderung eines umweltschonenden Energiepflanzenanbaus. Naturschutz und Landschaftsplanung 42:101107.

Hall, R.L., Allen, S.J., Rosier, P.T.W., Smith, D.M., Hodnett, M.G., Roberts, J.M.; Hopkins, R. \& Davies, H.N. (1996). Hydrological effects of short rotation energy coppice. Institute of Hydrology, Wallingford, UK.

Hampicke, U. (1992). Ökologische Ökonomie. UTB für Wissenschaft 1650, Ulmer: Stuttgart, $342 \mathrm{pp}$.

Haslett, J.R., Berry, P.M., Bella, G., Jongman, R.H.G., Pataki, G., Samways, M.J. \& Zobel, M. (2010). Changing conservation strategies in Europe: A framework integrating ecosystem services and dynamics. Biodivers. Conserv. 19/10, pp 2963-2977

Hardin, G. (1968). The tragedy of the commons. Science 162:1243-1248. 
Heidmann, T., Thomsen, A. \& Schelde, K. (2000). Modelling soil water dynamics in winter wheat using different estimates of canopy development. Ecological Modelling 129:229243.

Hillier, J., Whittaker, C., Dailey, G., Aylotts, M., Casella, E., Richter, G.M., Riche, A., Murphy, R., Taylor, G. \& Smith, P. (2009). Greenhouse gas emissions from four bioenergy crops in England and Wales: Integrating spatial estimates of yield and soil carbon balance in life cycle analysis. GCB Bioenergy 1:267-281

Janssen, G., Albrecht, J. (2008). Umweltschutz im Planungsrecht - Die Verankerung des Klimaschutzes und des Schutzes der biologischen Vielfalt im raumbezogenen Planungsrecht. Dessau-Roßlau (UBA-Texte 10/2008).

Kavalov, B., Peteves, S.D. (2005). Status and perspectives of biomass-to-liquid fuels in the European Union. Mission of the Institute for Energy Office for Official Publications of the European Communities, Luxembourg.

Kort, J., Collins, M. \& Ditsch, D. (1998). A review of soil erosion potential associated with biomass crops. Biomass Bioenergy 14:351-359.

Lee, Y. H., Bückmann, W. \& Haber, W. (2008). Bio-Kraftstoff, Nachhaltigkeit, Natur- und Bodenschutz. NuR, pp. 821-831.

Liesebach, M., Mulsow, H. (2003). Der Sommervogelbestand einer Kurzumtriebsplantage, der umgebenden Feldflur und des angrenzenden Fichtenwaldes im Vergleich. Die Holzzucht 54:27-31.

Londo, M., Roose, M., Dekker, J. \& Degraaf, H. (2004). Willow short-rotation coppice in multiple land-use systems: evaluation of four combination options in the Dutch context. Biomass and Bioenergy 27:205-221.

MEA (Millennium Ecosystem Assessment) (2005). Ecosystem and human well-beeing: Scenarios, Vol. 2. Findings of the Scenarios Working Group. Island Press: Washington, Covelo, London.

Mclaughlin, S.B., Walsh, M.E. (1998). Evaluating environmental consequences of producing herbaceous crops for bioenergy. Biomass and Bioenergy 14:317-324.

Müller, F., Burkhard, B. (2007). An ecosystem based framework to link landscape structures, functions and services. In: Mander, U., Wiggering, H. \& Helming, K. (Eds.): Multifunctional land use - Meeting future demands for landscape goods and services. pp 37-64. Springer: Berlin, Heidelberg, New York.

NABU (Naturschutzbund Deutschland e.V.) (2005). Nachwachsende Rohstoffe und Naturschutz: Argumente des NABU an einen naturverträglichen Anbau. NABU Positionspapier 04/2005. (online: http://www.nabu.de/imperia/md/content/nabude/energie/ biomasse/1.pdf access: 7.6. 2010).

NABU (Naturschutzbund Deutschland e.V.) (2007). Grünlandumbruch und Maisanbau in Natura 2000-Gebieten: Ein Fallbeispiel aus der Eifel. NABU: Berlin.

Peters, W. (2009). Biomassepotenziale aus der Landschaftspflege in Sachsen. FuE-Bericht im Auftrag des Sächsischen Landesamtes für Umwelt, Landwirtschaft und Geologie (unpublished), Bosch \& Partner, Berlin.

Petrak, M. (2009). Schwarzwild - Gewinner in der Kulturlandschaft: Wildbiologische Grundlagen und Empfehlungen für die Praxis von Jagd und Naturschutz, Forstwirtschaft und Landwirtschaft. Säugetierkundliche Informationen 7:255-267. 
Rode, M., Schneider, C., Ketelhake, G. \& Reißhauer, D. (2005). Naturschutz-verträgliche Erzeugung und Nutzung von Biomasse zur Wärme- und Stromgewinnung. BfN-Scripten 136, Bonn.

Rowe, R.L., Street, N.R. \& Taylor, G. (2009). Identifying potential environmental impacts of large-scale deployment of dedicated bioenergy crops in the EU. Renewable and Sustainable Energy Reviews 13: 271-290.

Schrack, M. (2001). Zur naturschutzgerechten Ackerbewirtschaftung im Landschaftsschutzgebiet Moritzburger Kleinkuppenlandschaft. StUFA: Naturschutz regional - Beiträge zum Naturschutz im Oberen Elbtal/Osterzgebirge. pp. 70-82, Radebeul.

Spangenberg, J.H. (2008). Second order governance: learning processes to identify indicators. Corporate Social Responsibility and Environmental Management 15:125-139.

SRU (Sachverständigenrat für Umweltfragen) (2007). Klimaschutz durch Biomasse. Sondergutachten, Bonn.

Stegner, J. (2010). Rahmenkonzept zur energetischen Verwertung von Biomasse aus der Landschaftspflege im Freistaat Sachsen. Abschlussbericht im Auftrag des Sächsischen Staatsministeriums für Umwelt und Landwirtschaft (unpublished), Dresden, $154 \mathrm{p}$

TEEB (The Economics of Ecosystems and Biodiversity) (2009). TEEB for Policy Makers. Responding to the value of nature.

UFOP (Union zur Förderung von Energie- und Proteinpflanzen e.V.) (2006). Biodiesel und pflanzliche Öle als Kraftstoffe - aus der Nische in den Kraftstoffmarkt. Stand und Entwicklungsperspektiven. UFOP, Berlin.

Vetter, A. (2001). Qualitätsanforderungen an halmgutartige Bioenergieträger hinsichtlich der energetischen Verwertung. In: Fachagentur Nachwachsende Rohstoffe (Ed.): Energetische Nutzung von Stroh, Ganzpflanzengetreide und weiterer halmgutartiger Biomasse. Stand der Technik und Perspektiven für den ländlichen Raum. Gülzower Fachgespräche 17:36-50.

Wachendorf, M., Grass, R. \& Richter, F. (2008). Exploiting the biomass from nature conservation areas for energetic purposes. Proc. 16th Europ. Biomass Conf., Valencia, pp. $1-6$.

Windhorst, W., Müller, F. \& Wiggering, H. (2004). Umweltziele und Indikatoren für den Ökosystemschutz. Geowissen und Umwelt. Springer, pp 345-373 